\title{
ANALYSIS OF ORGANIC MATERIAL CONTENT AND ABUNDANCE OF MACROZOOBENTHOS IN THE SOUTH BENGKALIS ISLAND, RIAU PROVINCE
}

\author{
Muhamad Razid ${ }^{1}$, Bintal Amin ${ }^{1}$, Efriyeldi $^{1}$ \\ ${ }^{1}$ Department of Marine Science, Faculty of Fisheries and Marine Universitas Riau, Pekanbaru \\ *muhamad.razid0475@student.unri.ac.id
}

\begin{abstract}
This study was conducted in July-August 2020 by using sediment samples and macrozoobenthos in the southern part of Bengkalis Island, Riau Province. The aim of this study is to find out how much the organic matter content, the abundance of macrozoobenthos, and the correlation between the organic matter content of the sediments to the abundance of macrozoobenthos. This study used a survey method consisting of 3 stations with 3 transects in each station. The organic matter content of sediments revolved from 4.85 to $8.52 \%$ in the waters of the southern part of Bengkalis Island. The highest organic matter content was at station III, namely $8.52 \%$, while the lowest organic matter content was at station II namely $4.85 \%$. The abundance of organisms found at the three research stations was 4.04 to 5.96 ind $/ \mathrm{m} 2$. The abundance average at all macrozoobenthic research stations was $4.93 \mathrm{ind} / \mathrm{m} 2$. The results of simple linear regression analysis of organic matter content and abundance of macrozoobenthos showed a very weak correlation.
\end{abstract}

Keywords: Makrozoobenthos, Sediment, Abundance, Organic matter, Riau

\section{PENDAHULUAN}

Pulau Bengkalis merupakan salah satu pulau yang berada di Provinsi Riau yang terletak di Pesisir Timur Sumatera. Pulau ini mempunyai lokasi yang strategis di Provinsi Riau karena berbatasan langsung dengan negara Malaysia. Bagian Selatan Pulau Bengkalis merupakan daerah yang berbatasan dengan Pulau Padang Kabupaten Meranti dan Selat Bengkalis. Daerah ini terdapat berbagai macam aktivitas kapal baik perikanan tangkap maupun kapal transportasi sehingga dapat menyumbangkan material organik dan anorganik. Bahan organik dan anorganik dapat memberikan dampak bagi makhluk hidup yang ada pada kawasan pesisir di wilayah tersebut. Bahan organik merupakan salah satu faktor yang mempengaruhi kesuburan perairan juga merupakan faktor seringnya terjadi pencemaran yang berpengaruh terhadap kelestarian keanekaragaman hayati pada perairan tersebut.

Salah satu organisme yang dapat berpengaruh adalah makrozoobentos, karena organisme ini hidupnya menetap. Makrozoobentos memiliki kemampuan untuk mengakumulasi suatu bahan pencemar di dalam tubuhnya, berperan penting dalam proses dekomposisi dan mineralisasi material organik yang memasuki perairan serta bahan organik juga sebagai pendukung kehidupan makrozoobentos.

Makrozoobentos juga memegang peranan penting sebagai detritivor pada substrat sehingga dapat dijadikan indikator keseimbangan dalam suatu ekosistem. Ketersediaan bahan organik sedimen dapat memberikan variasi terhadap kelimpahan organisme yang ada. 
Sehubungan dengan peranan makrozoobentos tersebut dan belum pernah dilakukan penelitian tentang ini di perairan bagian Selatan Pulau Bengkalis maka penulis tertarik melakukan penelitian mengenai analisis kandungan bahan organik sedimen dan kelimpahan makrozoobentos di perairan bagian Selatan Pulau Bengkalis Provinsi Riau

\section{METODE PENELITIAN} Waktu dan Tempat

Penelitian ini dilaksanakan pada bulan Juli-Agustus 2020 yang bertempat di wilayah Selatan Pulau Bengkalis Provinsi Riau (Gambar 1). Analisis sampel bahan organik sedimen dilakukan di Laboratorium Kimia Laut dan identifikasi makrozobentos di Laboratorium Biologi Laut Fakultas Perikanan dan Kelautan Universitas Riau.

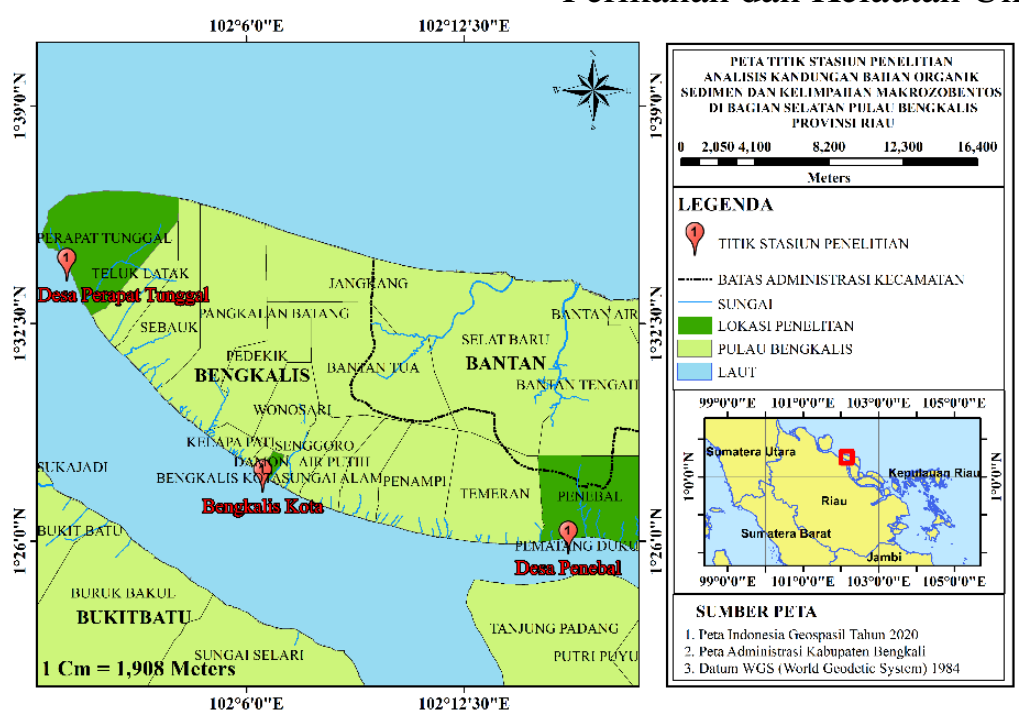

Gambar 1. Lokasi Penelitian

\section{Metode Penelitian}

Metode yang digunakan dalam penelitian ini adalah metode survei. Data didapatkan melalui pengamatan dan pengukuran di lapangan dan kemudian sampel sedimen dan makrozoobentos dibawa ke laboratorium untuk dianalisis dan di identifikasi.

\section{Prosedur Penelitian}

\section{Pengukuran Kualitas Perairan}

Pengukuran parameter kualitas air diukur pada perairan di masing-masing stasiun saat pengambilan sampel yang bertujuan untuk menggambarkan kondisi perairan pada saat penelitian. Parameter lingkungan yang diukur adalah suhu, $\mathrm{pH}$, salinitas dan kekeruhan.

\section{Pengambilan Sampel Makrozoobentos}

Sampel makrozoobentos dilakukan menggunakan sekop dengan kedalaman 10 cm pada subplot ukuran $1 \times 1 \mathrm{~m}^{2}$. Sampel sedimen yang didapatkan lalu disaring menggunakan ayakan dengan ukuran mata saring $1 \mathrm{~mm}$ untuk memperoleh Makrozoobentos, selanjutnya di masukkan ke dalam kantong plastik ukuran $1 \mathrm{~kg}$. Kemudian sampel tersebut diawetkan dengan menggunakan formalin $10 \%$ dan diberi label plot dan subplot, kemudian sampel dimasukkan ke dalam box dan dibawa ke laboratorium untuk diidentifikasi dan selama di laboratorium formalin diganti dengan alkohol $70 \%$.

\section{Pengambilan Sampel Sedimen}

Pengambilan sampel sedimen untuk analisis fraksi dilakukan menggunakan pipa paralon dengan diameter $10 \mathrm{~cm}$ dan kedalaman $10 \mathrm{~cm}$ pada setiap titik sampling. Pengambilan sampel sedimen untuk analisis fraksi sedimen dilakukan 3 pengulangan dalam pengambilan 1 plot. 
Kemudian sampel sedimen yang diambil sebanyak $500 \mathrm{~g}$ dan selanjutnya sampel tersebut dimasukkan ke dalam kantong plastik yang telah diberi label berdasarkan titik sampling dan stasiunnya, kemudian sampel dimasukkan ke dalam box untuk dianalisis di laboratorium.

\section{Analisis Sampel Sedimen}

Pengamatan Untuk mengetahui kandungan bahan organik total sedimen dilakukan dengan menggunakan rumus:

$$
\text { Zat Organik Total }=\frac{a-c}{a-b} \times 100 \%
$$

Keterangan:

$$
\begin{aligned}
\mathrm{a}= & \text { Berat cawan dan sampel sedimen } \\
& \text { sebelum pembakaran } 550{ }^{\circ} \mathrm{C} \text { atau } \\
& \text { sesudah pengeringan } 105{ }^{\circ} \mathrm{C}(\mathrm{g}) \\
\mathrm{b}= & \text { Berat cawan }(\mathrm{g}) \\
\mathrm{c}= & \text { Berat cawan dan sampel sedimen } \\
& \text { sesudah pembakaran } 550^{\circ} \mathrm{C}(\mathrm{g})
\end{aligned}
$$

\section{Analisis Sampel Makrozoobentos}

Untuk mengetahui kelimpahan jenis makrozoobentos digunakan rumus [1] sebagai berikut :

Keterangan:

$$
\mathrm{K}=\frac{\mathrm{ni}}{\mathrm{A}}
$$

$$
\begin{aligned}
\mathrm{K}= & \text { Kelimpahan jenis (ind } \left./ \mathrm{m}^{2}\right) \\
\mathrm{ni}= & \text { Jumlah total individu } \\
& \text { Makrozoobentos } \\
& \text { tertangkap dalam A (ind) } \\
\mathrm{A}= & \begin{array}{l}
\text { Luas area pengambilan } \\
\\
\left(\mathrm{m}^{2}\right)
\end{array}
\end{aligned}
$$

Indeks kelimpahan relatif makrozoobentos dihitung berdasarkan rumus [1], sebagai berikut:

Keterangan:

$$
\mathbf{R}=\mathbf{n i} / \mathbf{N} \times 100
$$

$\mathrm{R}=$ Kelimpahan relatif

$\mathrm{Ni}=$ Jumlah individu setiap jenis

$\mathrm{N}=$ Jumlah seluruh indivudu
Untuk melihat hubungan antara kandungan bahan organik dengan kelimpahan makrozoobentos diketahui dengan menggunakan uji regresi linier sederhana. Persamaan regresi linier sederhana menurut [2] dapat dilihat dari persaman matematis yaitu:

Keterangan:

$$
\mathbf{Y}=\mathbf{a}+\mathbf{b x}
$$

$\mathrm{Y}=$ Kelimpahan makrozoobentos (ind $\left./ \mathrm{m}^{2}\right)$

$\mathrm{x}=$ Kandungan bahan organik (\%)

$\mathrm{a}=$ Konstanta

$\mathrm{b}=$ Konstanta

\section{HASIL DAN PEMBAHASAN}

Kondisi Umum Lokasi Penelitian

Kabupaten Bengkalis merupakan salah satu kabupaten yang terletak di pesisir timur pulau Sumatera dan wilayah Kepulauan dengan luas $7773.93 \mathrm{~km}^{2}$ berada pada posisi 2 $2^{\circ} 7^{\prime} 37.2^{\prime \prime}-0^{\circ} 55^{\prime} 33.6^{\prime \prime}$ LU dan $100^{\circ} 57^{\prime} 6$ "'-102 30 '25.2'BT. Lokasi pengambilan sampel dibagi menjadi tiga stasiun. Stasiun I berlokasi di perairan Desa Penebal pada koordinat $01^{\circ} 26^{\prime} 06.08$ " LU dan $102^{\circ} 15^{\prime} 36.41^{\prime \prime}$ BT. Stasiun II berada di perairan Bengkalis Kota pada koordinat $01^{\circ} 27^{\prime} 41.75^{\prime \prime}$ LU dan $102^{\circ} 066^{\prime} 52.58^{\prime \prime}$ BT dan Stasiun III berada di perairan Desa Perapat Tunggal pada koordinat 01 34'15.49” LU dan $102^{\circ} 00$ '37.79" BT.

\section{Pengukuran Kualitas Perairan}

Parameter kualitas perairan yang diukur di stasiun penelitian Pulau Bengkalis dapat dilihat di tabel 1. Dapat diketahui bahwa nilai $\mathrm{pH}$ air di Pulau Bengkalis yaitu 8,58 Nilai pengukuran suhu berkisar antara $25-26^{\circ} \mathrm{C}$ dengan nilai ratarata yaitu $25,6^{\circ} \mathrm{C}$. Nilai pengukuran kecerahan berkisar antara 8-15 cm dengan nilai rata-rata yaitu $11 \mathrm{~cm}$. Nilai pengukuran salinitas berkisar antara 26$27 \%$ dengan nilai rata-rata yaitu $26,3 \%$. Untuk melihat parameter kualitas perairan secara umum dapat dilihat pada Tabel 1 . 
Tabel 1. Parameter Kualitas Perairan

\begin{tabular}{cccccl}
\hline Stasiun & Suhu $\left({ }^{\circ} \mathbf{C}\right)$ & pH & Kecerahan $(\mathbf{c m})$ & Salinitas (\%o) & \multicolumn{1}{c}{ Kondisi perairan } \\
\hline I & 26 & 8,54 & 15 & 27 & $\begin{array}{l}\text { Pasang menuju surut, } \\
\text { mangrove, aktivitas budid aya } \\
\text { vanname, cerah }\end{array}$ \\
II & 25 & 8,65 & 10 & 26 & $\begin{array}{l}\text { Surut menuju pasang, aktivitas } \\
\text { nelayan, pemukiman, cerah } \\
\text { Surut menuju pasang, aktivitas } \\
\text { nelayan, pemukiman, wisata, } \\
\text { cerah }\end{array}$ \\
III & 26 & 8,56 & 8 & 26 & 26,3
\end{tabular}

\section{Kandungan Bahan Organik Sedimen}

Hasil analisis kandungan bahan organik sedimen pada masing-masing stasiun pengamatan dapat diketahui memiliki nilai yang berbeda-beda, persentase kandungan bahan organik sedimen di perairan bagian selatan Pulau Bengkalis dapat dilihat pada Tabel 2.

Tabel 2. Analisis Bahan Organik Sedimen

\begin{tabular}{cc}
\hline Stasiun & $\begin{array}{c}\text { bahan organik total } \\
\mathbf{\mathbf { S t d }} \mathbf{\text { Dev }}(\mathbf{\%})\end{array}$ \\
\hline I & $6,25 \pm 2,32$ \\
II & $4,85 \pm 1,30$ \\
III & $8,52 \pm 0,45$ \\
\hline Rata-rata & $6,54 \pm 0,94$ \\
\hline
\end{tabular}

Hasil analisis kandungan bahan organik di perairan bagian selatan Pulau Bengkalis berkisar antara 2,97 - 10,52\%. Bahan organik sedimen tertinggi terdapat di stasiun III transek 1 pada plot 1 yaitu 10,52 $\%$, sedangkan bahan organik sedimen terendah terdapat di stasiun I Transek 2 pada plot 3 yaitu $2,97 \%$ dan nilai rata-rata bahan organik sedimen di stasiun I yaitu $6,25 \%$ stasiun II yaitu $4,85 \%$ dan stasiun III yaitu $8,52 \%$.

Berdasarkan hasil uji anova diperoleh kandungan bahan organik setiap stasiun berbeda nyata karena nilai signifikan yang diperoleh $<0,05$ yaitu 0,02 . Sehingga dilakukan uji lanjut yang menyatakan bahwa stasiun I berbeda nyata dengan stasiun II, stasiun I dengan stasiun III berbeda nyata, dan stasiun II dengan stasiun III berbeda nyata.
Menurut [3], tingginya bahan organik yang masuk ke perairan berasal dari peningkatan aktivitas didaratan seperti pemupukan di sawah dan tambak, budidaya, industri dan aktivitas rumah tangga yang masuk kedalam perairan. Menurut [4], muara sungai sangat kaya akan bahan organik yang disebabkan oleh partikel yang mengendap di air laut maupun air tawar pada umumnya mengandung bahan organik.

[5] menyatakan bahwa dasar perairan berlumpur kaya akan bahan organik yang berasal dari vegetasi yang berada diatas daerah tersebut. Detritus mangrove akan membentuk partikel- partikel organik yang disebarkan ke seluruh perairan dan menjadi unsur hara yang penting bagi beberapa organisme daerah hutan mangrove. Dasar perairan berlumpur kaya akan bahan organik yang berasal dari vegetasi yang berada di atas daerah tersebut. Detritus mangrove akan membentuk partikelpartikel organik yang disebarkan ke seluruh perairan dan menjadi unsur hara yang penting bagi beberapa organisme daerah hutan mangrove. Menurut [6], organisme yang hidup di perairan seperti makrozoobentos sangat peka terhadap perubahan kualitas air tempat hidupnya sehingga akan berpengaruh terhadap komposisi dan kelimpahannya.

\section{Jenis dan Kelimpahan Makrozoobentos Jenis makrozoobentos yang} ditemukan di perairan bagian selatan Pulau Bengkalis terdapat 13 spesies dan memiliki 
jenis spesies yang hampir sama antar stasiunnya. Untuk mengetahui jenis makrozoobentos yang terdapat di perairan bagian selatan Pulau Bengkalis dapat dilihat pada Tabel 3 .

Tabel 3. Jenis Makrozoobentos yang Terdapat di Perairan Bagian Selatan Pulau Bengkalis

\begin{tabular}{lll}
\hline \multicolumn{1}{c}{ Kelas } & \multicolumn{1}{c}{ Famili } & \multicolumn{1}{c}{ Spesies } \\
\hline Gastropoda & Littorinidae & Littoraria $\mathrm{sp}$ \\
& Potamididae & Cerithidea $\mathrm{sp}$ \\
& Telescopium & Telescopium telescopium \\
& Melonginidae & Volema myristica \\
& Muricidae & Chicoreus capucinus \\
& Niritidae & Nerita lineata \\
& Nassaridae & Nassarius $\mathrm{sp}$ \\
& Naticidae & Natica tigrina \\
& Assimineidae & Sphaerassiminea miniata \\
& Neritidae & Neritina violacea \\
Bivalva & Placunidae & Placuna placenta \\
Malacostraca & Grapsidae & Metopograpsus $\mathrm{sp}$ \\
Merostomata & Limulidae & Belangkas \\
\hline
\end{tabular}

Berdasarkan hasil uji anova diperoleh bahwa kelimpahan makrozoobentos setiap stasiun tidak berbeda nyata karena nilai signifikan yang diperoleh $>0,05$ yaitu 0,072 , maka tidak perlu dilakukan uji lanjut.

Kelimpahan makrozoobentos yang telah diamati pada setiap stasiun berbedabeda. Kisaran nilai kelimpahan organisme yang terdapat pada ketiga stasiun penelitian yaitu $4,04-5,96 \mathrm{ind} / \mathrm{m}^{2}$. Dimana nilai kelimpahan individu yang tertinggi terdapat pada stasiun II yaitu $5,96 \mathrm{ind} / \mathrm{m}^{2}$ dan nilai kelimpahan individu yang terendah terdapat pada stasiun 3 yaitu $4,04 \mathrm{ind} / \mathrm{m}^{2}$. Rata-rata kelimpahan pada seluruh stasiun penelitian makrozoobentos yaitu $4,93 \mathrm{ind} / \mathrm{m}^{2}$. Untuk mengetahui nilai rata-rata kelimpahan makrozoobentos dan kelimpahan relatif dapat dilihat pada Tabel 4.

Tabel 4. Rata-rata Kelimpahan dan Kelimpahan Relatif Makrozoobentos

\begin{tabular}{|c|c|c|c|c|c|}
\hline \multirow{2}{*}{ Spesies } & \multicolumn{3}{|c|}{ Stasiun } & \multirow{2}{*}{$\begin{array}{c}\text { Kelimpahan } \\
\text { Makrozoobentos (ind } / \mathbf{m}^{2} \text { ) }\end{array}$} & \multirow{2}{*}{$\begin{array}{l}\text { Kelimpahan } \\
\text { Relatif (\%) }\end{array}$} \\
\hline & 1 & 2 & 3 & & \\
\hline Littoraria $\mathrm{sp}$ & 0,78 & 0,15 & 0 & 0,31 & 6,82 \\
\hline Cerithidea $\mathrm{sp}$ & 0,67 & 0,78 & 2,67 & 1,37 & 31,64 \\
\hline Telescopium telescopium & 0,63 & 0,33 & 0 & 0,32 & 5,73 \\
\hline Volema myristica & 1,44 & 2,82 & 1,26 & 1,84 & 35,07 \\
\hline Chicoreus capucinus & 0,44 & 0,04 & 0 & 0,16 & 3,46 \\
\hline Nerita lineata & 0,04 & 0,11 & 0 & 0,05 & 1,2 \\
\hline Nassarius sp & 0,56 & 1,22 & 0,11 & 0,63 & 11,36 \\
\hline Natica tigrina & 0,04 & 0,15 & 0 & 0,06 & 0,85 \\
\hline Sphaerassiminea miniata & 0,11 & 0,07 & 0 & 0,06 & 1,26 \\
\hline Neritina violacea & 0,04 & 0 & 0 & 0,01 & 0,24 \\
\hline Placuna placenta & 0 & 0,04 & 0 & 0,01 & 0,55 \\
\hline Metopograpsus sp & 0,07 & 0,22 & 0 & 0,1 & 1,61 \\
\hline Belangkas & 0 & 0,04 & 0 & 0,01 & 0,15 \\
\hline Jumlah & 4,82 & 5,97 & 4,04 & 4,92 & 100 \\
\hline
\end{tabular}




\section{Jenis Fraksi Sedimen}

Secara umum jenis fraksi sedimen yang terdapat di perairan bagian selatan Pulau Bengkalis adalah lumpur berpasir. Kisaran fraksi lumpur sedimen di daerah tersebut berkisar antara 46,90 - 89,08\%. Fraksi lumpur sedimen tertinggi terdapat di stasiun II transek 3 pada plot 2 yaitu $89,08 \%$, sedangkan fraksi lumpur sedimen terendah terdapat di stasiun I transek 1 pada plot 3 yaitu 46,90\%. Kisaran fraksi berpasir di daerah tersebut berkisar antara 10,26$50,25 \%$. Fraksi berpasir sedimen tertinggi terdapat di stasiun I transek 2 pada plot 1 yaitu $50,25 \%$, sedangkan fraksi berpasir sedimen terendah terdapat di stasiun II transek 3 pada plot 2 yaitu 10,26\%. Kisaran fraksi kerikil di daerah tersebut berkisar antara 0,11-6,13\%. Fraksi kerikil sedimen tertinggi terdapat di stasiun I transek 3 pada plot 3 yaitu $6,13 \%$, sedangkan fraksi kerikil sedimen terendah terdapat di stasiun III transek 1 pada plot 3 yaitu $0,11 \%$. Untuk mengetahui persentase analisis fraksi sedimen di perairan bagian selatan Pulau Bengkalis dapat dilihat pada Tabel 5.

Tabel 5. Analisis Fraksi Sedimen di perairan bagian selatan Pulau Bengkalis

\begin{tabular}{ccccc}
\hline \multirow{2}{*}{ Stasiun } & \multicolumn{3}{c}{ Fraksi sedimen (\%) } & \multirow{2}{*}{ Jenis fraksi } \\
\cline { 2 - 4 } & Kerikil & Pasir & Lumpur & \\
\hline I & 3,17 & 40,52 & 56,31 & Lumpur berpasir \\
II & 1,91 & 27,79 & 70,29 & Lumpur berpasir \\
III & 1,90 & 16,13 & 81,97 & Lumpur \\
\hline
\end{tabular}

Hubungan Kandungan Bahan Organik dengan Kelimpahan Makrozoobentos di Perairan Bagian Selatan Pulau Bengkalis

Hasil analisis hubungan kandungan bahan organik dan kelimpahan makrozoobentos di perairan bagian selatan Pulau Bengkalis diperoleh nilai koefisien determinan $\left(\mathrm{R}^{2}\right)$ yaitu 0,0168 ini artinya pengaruh kandungan bahan organik terhadap kelimpahan makrozoobentos di perairan bagian selatan Pulau Bengkalis sebesar $16,8 \%$ sedangkan $83,2 \%$ lagi diduga dipengaruhi oleh faktor lain, seperti jenis substrat, vegetasi mangrove dan aktivitas masyarakat. Nilai koefisien relatif (r) yang terdapat pada lokasi penelitian yaitu $0,1296 \%$ dengan persamaan regresi $\mathrm{Y}=17,54-0,416 \mathrm{X})$ yang menyatakan bahwa hubungan kandungan bahan organik dan kelimpahan makrozoobentos di perairan bagian selatan Pulau Bengkalis adalah sangat lemah. Hal ini sama dengan penelitian yang di lakukan oleh [7].

Hasil analisis regresi linier antara kandungan bahan organik sedimen dengan kelimpahan makrozoobentos di perairan Selat Panjang diperoleh nilai koefisien determinasi $\left(\mathrm{R}^{2}\right)$ 0,107 dan nilai koefisien korelasi (r) 0,327 dengan persamaan regresi $\mathrm{Y}=156,087+150,696 \mathrm{X}$ yang menggambarkan bahwa hubungan antara kandungan bahan organik sedimen dengan kelimpahan makrozoobentos di perairan Selat Panjang sangat lemah (Gambar 2).

Rendahnya kandungan bahan organik pada stasiun I dan II disebabkan oleh substrat dasar dari stasiun ini didominasi oleh fraksi lumpur berpasir, berbeda dengan stasiun III yang didominasi oleh fraksi lumpur dan serasah batang kayu yang berada di sekitar perairan tersebut memberikan sumbangan bahan organik ke dalam perairan. Sehingga stasiun ini memiliki kandungan bahan organik yang tinggi sedangkan stasiun ini memiliki nilai kelimpahan makrozoobentos yang rendah yaitu $4,04 \mathrm{ind} / \mathrm{m}^{2}$. Hal ini diduga terjadi karena dipengaruhi oleh faktor lingkungan perairan lainnya seperti BOD dan oksigen terlarut. Jika bahan organik tinggi maka oksigen yang dibutuhkan oleh mikroorganisme untuk menguraikan bahan organik tersebut juga tinggi, sehingga oksigen terlarut yang dapat dimanfaatkan 
oleh makrozoobentos menjadi sedikit, hal ini dapat mengganggu kehidupan

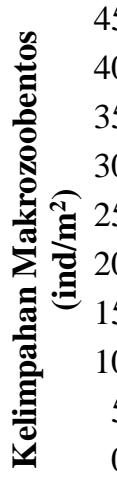

organisme makrozoobentos.

termasuk
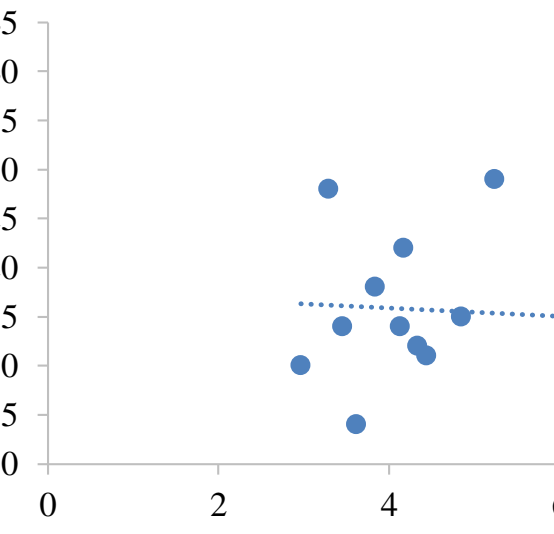

$$
\begin{gathered}
\mathrm{y}=-0,4165 \mathrm{x}+17,54 \\
\mathrm{R}^{2}=0,0168 \\
\mathrm{r}=0,1296
\end{gathered}
$$

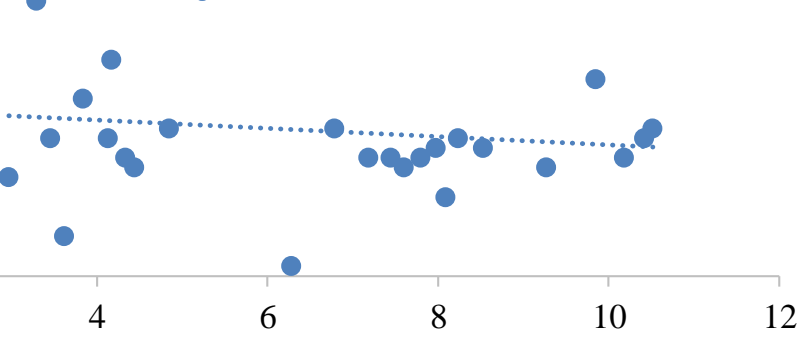

Bahan Organik Sedimen (\%)

Gambar 2. Hubungan Kandungan Bahan Organik Sedimen dengan Kelimpahan Makrozoobentos di Perairan Bagian Selatan Pulau Bengkalis.

\section{KESIMPULAN DAN SARAN Kesimpulan}

Kandungan bahan organik sedimen di perairan bagian selatan Pulau Bengkalis termasuk dalam kriteria sedang. Dimana nilai kelimpahan organisme yang terdapat pada ketiga stasiun penelitian yaitu 4,04$5,96 \mathrm{ind} / \mathrm{m}^{2}$. Rata-rata kelimpahan pada seluruh stasiun penelitian makrozoobentos yaitu $4,93 \mathrm{ind} / \mathrm{m}^{2}$. Hasil analisis regresi linier sederhana kandungan bahan organik dan kelimpahan makrozoobentos menunjukkan hubungan yang sangat lemah.

\section{Saran}

Perlu dilakukan penelitian lanjutan mengenai hubungan bahan organik dengan jenis fitoplankton yang terdapat di perairan Bengkalis

\section{DAFTAR PUSTAKA}

1. Kasry, A., N. Elfajri, dan R. Agustina. (2012). Penuntun Praktikum Ekologi Perairan. Fakultas Perikanan dan Ilmu Kelautan. Universitas Riau. Pekanbaru

2. Tanjung, A. (2014). Rancangan Percobaan. Tantaramesta. Bandung

3. Faizal, A., J. Jompa dan C. Rani. (2011). Dinamika Spasio-Temporal Tingkat Kesuburan Perairan di Kepulauan Spermonde Sulawesi Selatan. Jurusan Ilmu Kelautan, FKIP Universitas Hasanudin. Sulawesi Selatan.

4. Utama, R.P., S. Nedi, and A. Tanjung. (2019). Analysis Content of Organic Matter in Sediment and Abundance of Macrozoobenthos in Teluk Buo Padang West Sumatera. Asian Journal of Aquatic Sciences, 2(3) : 197-205

5. Hawari, A., B. Amin, dan Efriyeldi. (2013). Hubungan antara Bahan Organik Sedimen dengan Kelimpahan Makrozoobentos di Perairan Pantai Pandan Provinsi Sumatera Utara. Jurnal Online Mahasiswa Fakultas Perikanan dan Ilmu Kelautan, 1(2)

6. Musthofa, A., M. Muskananfola, dan S. Rudiyanti. (2014). Analisis Struktur Komunitas Makrozoobentos Sebagai Bioindikator Kualitas Perairan Sungai Wedung Kabupaten Demak. Diponegoro Journal of Maquares, 3(1): 81-88.

7. Silitonga, B. (2015). Analisis Kandungan Bahan Organik Sedimen dan Makrozoobentos di Perairan Selat Panjang Kabupaten Kepulauan Meranti Provinsi Riau. Fakultas Perikanan dan Ilmu Kelautan Universitas Riau. Pekanbaru 